UDC $81 ' 42$

DOI https://doi.org/10.32841/2409-1154.2021.48-1.16

\author{
Zabotnova M. V., \\ Postgraduate Student \\ Borys Grinchenko Kyiv University, \\ Senior Lecturer at the Department of Philology, Translation and Strategic Communication \\ National Academy of the National Guard of Ukraine
}

\title{
TEXTUALITY OF INTERNET MEMES IN ENGLISH POLITICAL DISCOURSE
}

\begin{abstract}
Summary. The article is devoted to textual peculiarities of Internet memes in English political discourse. The aim of this work is to figure out the classification of Internet memes political discourse based on their textuality. To achieve the aim there were completed the following tasks: observed the latest works devoted to Internet memes, figured out the types of memes implementation in political discourse, detected the specificity of political memes realization, and analyzed the frequency of political Internet memes usage based on their type. The author defines three key types of political Internet memes based on the levels of their textuality such as: textual (original, symbiotic, integral, fused, and phrasal), non-textual (original, fused, and pictorial), and animated (GIFs and fragmental). The practical material was purposefully selected from trendy social network such as Instagram; namely, the whole amount of material was chosen from official news agencies represented online such as BBC News, CNN, MSNBC, NBC News, The Times, Politico, and Washington Post. The author works out Internet memes based on political posts concerning the United States of America as well as the United Kingdom. The intention of memes' creation depends on the verbalization circumstances - in 2021 these factors are determined by the worldwide pandemic Covid-19, riots in the United States of America, British Royal family, lockdowns, and elections between the representative of the Republican Party the $45^{\text {th }}$ President of the United States of America - Donald Trump and the representative of the Democratic Party just-elected $46^{\text {th }}$ President of the United States of America - Joe Biden. Covid-19 is represented in a range of protective medical means such as: masks, medical gloves, and distancing, riots are verbalized through black-and-white colours. So, this selection of Internet memes targets at politicians' abilities and disabilities to override the chaos of recent days. The author concluded that textual memes have the biggest quantity of posts, non-textual memes occupy the second position, and animated memes occupy only the third position.
\end{abstract}

Key words: memes, political discourse, political memes, textuality, context.

Introduction. Internet memes have become inseparable element of interaction throughout social networks. Politics is not an exception. News Agencies which are represented in virtual media verbalize information using memes as a core way of data sharing. Such way of communication among numerous Internet users occupies the whole globe.

The first Internet meme which has been correlated with political activity was created in 2000 when the President of the USA mistakenly turned the word "Internet" into "Internets" (fig. 1), George W. Bush made the same mistake four years later debating with John Kerry [1].

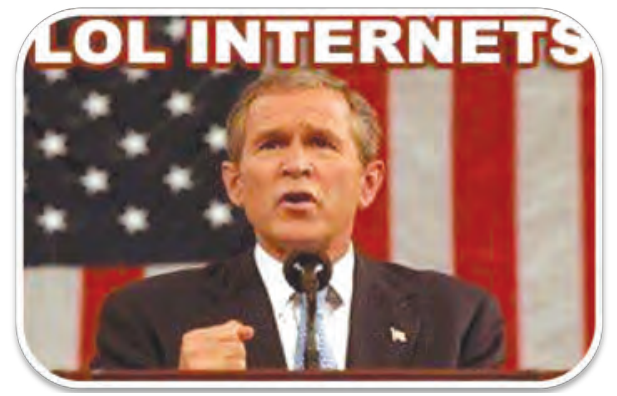

Fig. 1. "Internets" [1]

Many researchers devote their works to Internet memes: Davison P. [2] who writes about visual effects of memes, Dawkins R. [3] - the scholar who has coined out the term "memes", and Kulkarni A. [4] who discusses key features of political memes; to political discourse: Batsevych F. [5] who works with discourse and its classifications, T. van Dijk [6] who devotes his papers to all the discourse fields, etc.

The aim of this work is to figure out the classification of Internet memes political discourse based on their textuality.

To achieve the aim there is a need to complete the following tasks:

- to observe the latest works devoted to Internet memes;

- to figure out the types of memes implementation in political discourse;

- to detect the specificity of political memes realization;

- to analyze the frequency of political Internet memes usage based on their type.

The practical material has been purposefully selected from Internet-sites and social network Instagram including official News Agencies such as BBC News, CNN, MSNBC, NBC News, The Times, Politico, and Washington Post.

Cambridge Dictionary defines Internet memes as "a cultural feature or a type of behaviour that is passed from one generation to another, without the influence of genes" [7]. The concept "meme" was distinguished in 1976 by British scholar Dr. R. Dawkins, he compares them with living genes which can replicate "as genes propagate themselves in the gene pool by leaping from body to body via sperms or eggs, so memes propagate themselves in the meme pool by leaping from brain to brain via a process which, in the broad sense, can be called imitation" [3, p. 192]. At the same time, Bradly E. Wiggins compares Internet memes with, so called, artifacts which have become an essential part of digital culture [8, p. 6]. Later, in 2012, Shifman L. has proposed to define memes as "units of popular culture, imitated, and transformed by individual 
Internet users, creating a shared cultural experience in the process" [9, p. 367]. Nevertheless, Davison P. has pointed out that Internet meme is "a piece of culture, typically a joke, which gains influence through online transmission" [2, p. 122]. The scientist highlights three possible components of memes realization, such as: manifestation (meme's observable and external phenomena), behavior (action presented in the meme), and ideal (the concept or idea reflected by the meme).

Internet memes essential part of information presentation by news agencies. They ease the process of communication being accepted and used by huge number of users, moreover, they may attract more attention to political parties and their campaigns.

Politics is one of the most widely spread issue of modern social life. In the frames of political discourse, it is possible to figure out the following genres: government deliberations, parliamentary debates, party programs, and speeches by politicians [10, p. 212]. The Dutch researcher Teun van Dijk in his work "Political Discourse and Ideology" highlighted that not every piece of political affairs can be called political discourse, thus "informal conversation of a politician with her friends does not count as a political discourse: the discourse must be produced by the speaker in her professional role of a politician and in an institutional setting. In a more actionoriented way, we may also say that discourse is political when it accomplishes a political act in a political institution, such as governing, legislation, electoral campaigning, and so on" [10, p. 212]. Nevertheless, there arises one definite question - is it possible to include Internet memes with political contexts into the list of ways of verbalizing political discourse? It is essential, that all the memes are produced not by the politicians themselves but by the Internet users, IT managers of political campaigns as well as by the news agencies which inform the audience about the political issues. In the frames of our work, we consider that political Internet memes represent situations which involve all political spheres starting from news articles in social networks and finishing with political speeches, debates, and campaigns. Being created not by the politicians political Internet memes realize the wide range of politics-related components. Kulkarni A. in her work "Internet Memes and Political Discourse" [4, p. 14] includes to the list of memes' generators paid bloggers, micro bloggers and commenters who can be hired to process the political Internet memes formation.

\section{Results and discussions.}

In the frames of our research, we propose to divide political Internet memes into three types: textual, non-textual, and animated. Textual Internet memes are those which are followed with printed or written phrases as well as word-combination of different length and information capacity, non-textual are the memes which consist of pictures or photos without any printed or written phrase as well as word-combination. Animated memes are those which depict politicians within several seconds to show a repeated action. Each of these group can be divided into the following subgroups:

1) textual:

- original memes (fig. 2) consist of unmotivated photo which does not have any artificially implied information but has initial lexical message. They include printed passage which was not incorporated purposefully by meme's generator;

- symbiotic memes (fig. 3) consist of the combination of photo with incorporated passage. In the majority of cases such message is an abstract from the speech of the depicted politician or from the big informative article presented by any news agency;

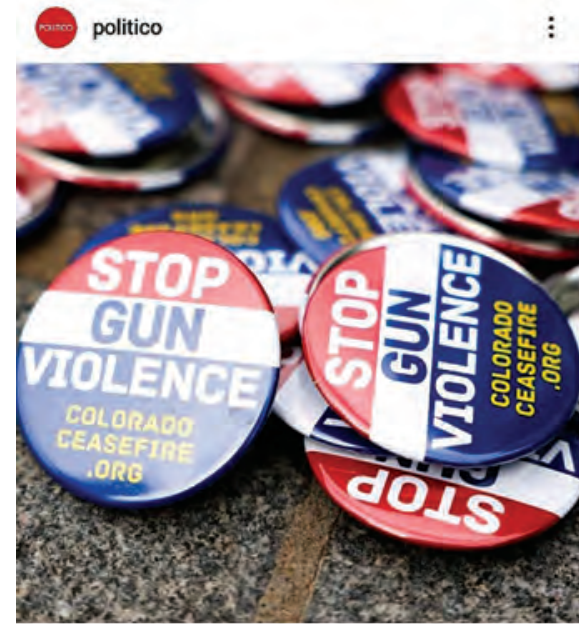

Fig. 2. "Textual Original Memes" [11]

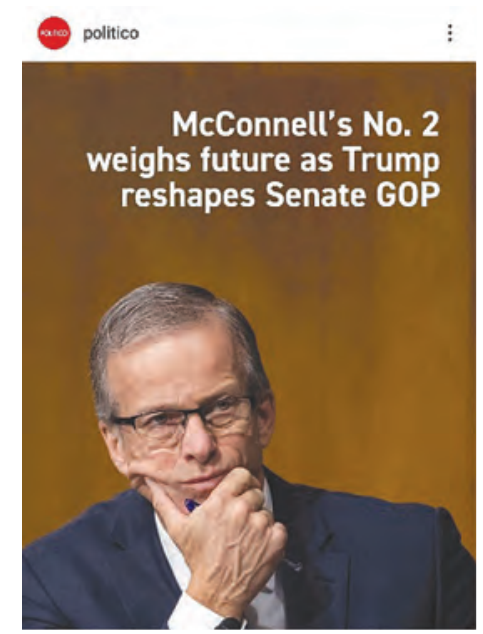

Fig. 3. "Textual Symbiotic Memes" [11]

- integral memes (fig. 4) consist of man-made picture which has inseparable lexical message. They can be compared with comics due to the similarity in their form and way of implementation;

- fused memes (fig. 5) consist of the combination of two or more pictures with short message. Mostly, they are represented by the political photo, and visual effects which help to add emotional marking to the meme and short written or printed passage which highlights the main purpose of political meme;

thetimes

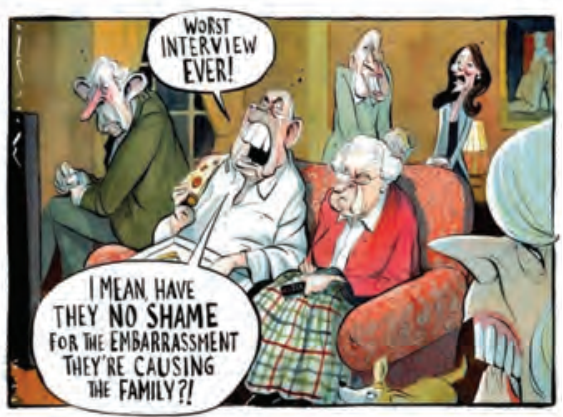

Fig. 4. "Textual Integral Memes" [12] 


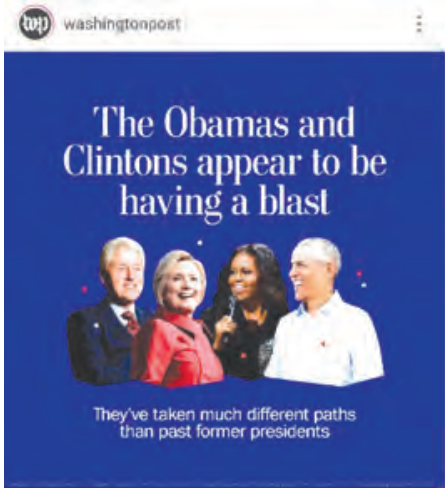

Fig. 5. "Textual Fused Memes" [13]

- phrasal memes (fig. 6) consist of text only. They are represented with the help of abstracts from the political speeches or from the political informative articles from different news agencies; nevertheless, such political Internet memes can include political quotes from speeches. The background of such memes does not have any picture, photo, or visual effects;

2) non-textual:

- fused memes (fig. 7) consist of combination of two or more manipulated pictures without lexical context. They are bright and serve to demonstrate all the important issues in one unit, that is achieved with the help of numerous visual effects, pictures, and photos mixed in different ways;

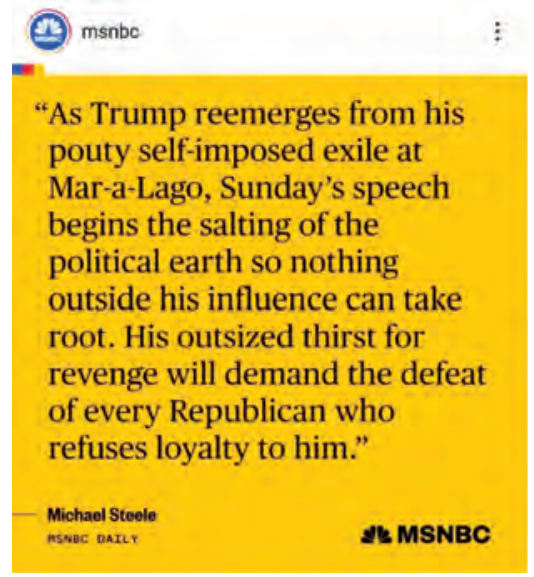

Fig. 6. “Textual Phrasal Memes” [14]

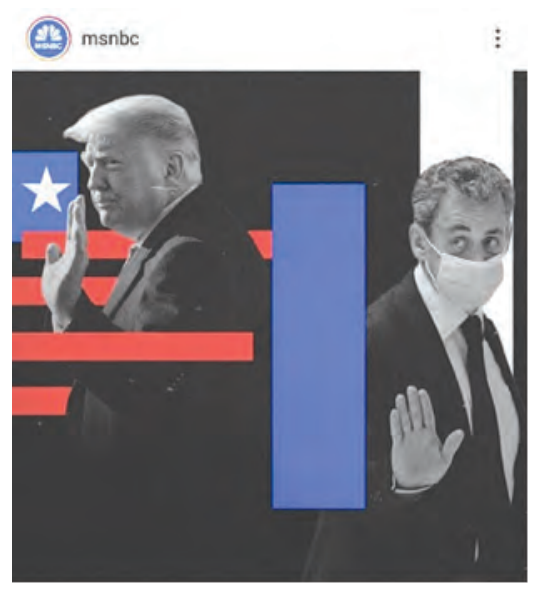

Fig. 7. "Non-textual Fused Memes" [14]
- original memes (fig. 8) consist of unmotivated photo which does not have any artificially implied information without lexical context. Mostly, those are the photos which become memes due to their presentation in social networks as well as due to their replication possibilities;

- pictorial memes (fig. 9) consist of man-made picture without lexical context. Such memes are implemented in the way of drawing or sketch that may have much in common with comics without written or printed lexical support.

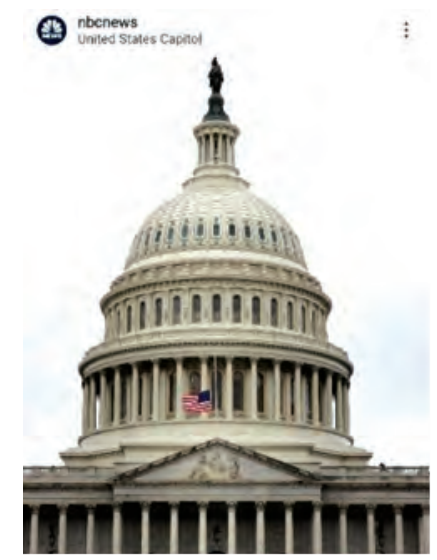

Fig. 8. "Non-textual Original Memes" [15]

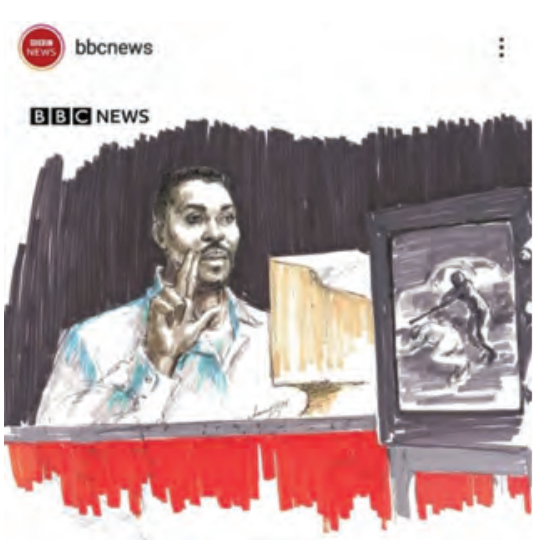

Fig. 9. "Non-textual Pictorial Memes" [16]

3) animated memes:

- GIFs are the memes which show video-fragment with short, repeated actions which were produced by politicians within few seconds. They are not used to inform but to show emotional response such as: excitement, interest, astonishment, etc.;

- fragmental memes are short videos which last up to thirty seconds and serve to provide Internet users with basic information.

So, to figure out the frequency of political Internet memes usage based on their textuality there is a need to systematize the purposefully selected units. There were 159 political memes under study, dated from the $1^{\text {st }}$ of March up to the $5^{\text {th }}$ of April 2021.

Out of 159 political Internet memes BBC News is represented by 15 units, CNN - by 20 units, MSNBC - by 47 units, NBC News by 28 units, The Times - by 8 units, Washington Post - by 16 units, and Politico - by 25 units. The table below shows the correlation between their quantity in each media source.

Textual memes have the biggest quantity of posts - 102 units whereas the most frequently used are symbiotic. Non-textual memes 
occupy the second position - 47 units, and animated memes have only 10 units. Furthermore, GIFs are not verbalized throughout Instagram news agencies.

Nevertheless, the $1^{\text {st }}$ table shows that NBC News agency is the only media resource which verbalizes its information with the help of various political Internet memes while The Times uses the least variety of meme types. Washington Post and CNN News do not post non-textual political memes.

Conclusions. Political Internet memes which are presented in Instagram by numerous online news agencies (BBC News, $\mathrm{CNN}$, MSNBC, NBC News, The Times, Politico, and Washington Post) have a wide range of implementation. In the frames of our work, we figured three main types and, as result, ten subtypes of political Internet memes such as textual memes (symbiotic, fused, original, integral, and phrasal), non-textual (original, fused, and pictorial), and animated (GIF and fragmental). Non-textual are less spread than textual and animated. The prospect of this work is to figure out informative capacity of each type of political Internet memes in the way of conducting online experiment among Englishspeaking users.

\section{References:}

1. Klein O. The Evolution of Political Internet Memes. Kennedy School Review: a Harvard Kennedy School Student Publication. 2019. URL: https://ksr.hkspublications.org/2019/03/11/the-evolution-of-politicalinternet-memes/

2. Davison P. The Language of Internet Memes. The Social Media Reader. NYU Press. 2012. P. 120-134.

3. Dawkins R. The Selfish Gene. Oxford University Press. UK. 2006. 236 p.

4. Kulkarni. A. Internet Memes and Political Discourse: a Study on the Impact of Internet Meme as a Tool in Communicating Political Satire. Journal of Content, Community and Communication. Vol. 6. 2017. P. 13-17.

5. Бацевич Ф.С. Основи комунікативної лінгвістики. Київ: Видавничий центр «Академія». 2004. 244 с.

6. Teun van Dijk. Discourse and Power. British Library. UK. 2008. 308 p.

7. Cambridge Dictionary. URL: https://dictionary.cambridge.org/dictionary/ english/meme

8. Wiggins B. E. Memes as Genre: a Structural Analysis of the memescape. New Media and Society. 2014. https://www.researchgate.net/ publication/288811719_Memes_as_genre_A_structural_analysis_of_ the memescape

9. Shifman. L. Memes in a Digital World: Reconciling with a Conceptual Troublemaker. Journal of Computer-Mediated Communication. 2013. P. 362-377.

10. Teun van Dijk. Political Discourse and Ideology. Doxa Communication. University of Amsterdam. Universitat Pompeu Fabra, Barcelona. 2020. P. 207-225,

11. Politico. Instagram. URL: https://www.instagram.com/politico/

12. The Times. Instagram. URL: https://www.instagram.com/thetimes/

13. Washington Post. Instagram. URL: https://www.instagram.com/ washingtonpost/

14. MSNBC. Instagram. URL: https://www.instagram.com/msnbc/

15. NBC News. Instagram. URL: https://www.instagram.com/nbcnews/

16. BBC News. Instagram. URL: https://www.instagram.com/bbcnews/

Заботнова М. В. Текстуальність інтернет-мемів в англомовному політичному дискурсі

Анотація. Стаття присвячена текстуальним особливостям інтернет-мемів в англомовному політичному дискурсі. Мета роботи полягає у визначенні класифікації інтернет-мемів у політичному дискурсі, спираючись

Table 1

\begin{tabular}{|c|c|c|c|c|c|c|c|c|c|}
\hline \multicolumn{10}{|c|}{ Frequency of memes usage } \\
\hline & & 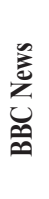 & 玄 & $\begin{array}{l}\text { Un } \\
\sum_{\sum}^{\infty} \\
\sum\end{array}$ & 兑 & $\begin{array}{l}\stackrel{\mathscr{\Xi}}{\Xi} \\
\stackrel{\Xi}{\Xi} \\
\stackrel{\Xi}{E}\end{array}$ & 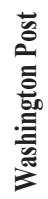 & 串 & $\begin{array}{l}\text { 离 } \\
\text { 音 } \\
\text { 范 }\end{array}$ \\
\hline \multirow{5}{*}{ Textual } & Original & 0 & 0 & 4 & 0 & 1 & 0 & 1 & 6 \\
\hline & Symbiotic & 8 & 7 & 1 & 6 & 0 & 4 & 13 & 49 \\
\hline & Integral & 1 & 0 & 0 & 0 & 4 & 0 & 0 & 5 \\
\hline & Fused & 0 & 2 & 5 & 1 & 0 & 5 & 0 & 13 \\
\hline & Phrasal & 0 & 0 & 19 & 5 & 0 & 2 & 3 & 29 \\
\hline \multirow{3}{*}{ Non-textual } & Original & 3 & 0 & 5 & 8 & 3 & 0 & 8 & 27 \\
\hline & Fused & 0 & 0 & 11 & 5 & 0 & 0 & 0 & 16 \\
\hline & Pictorial & 2 & 0 & 1 & 1 & 0 & 0 & 0 & 4 \\
\hline \multirow{2}{*}{ Animated } & GIFs & 0 & 0 & 0 & 0 & 0 & 0 & 0 & 0 \\
\hline & Fragmental & 1 & 1 & 1 & 2 & 0 & 5 & 0 & 10 \\
\hline \multicolumn{2}{|c|}{ Total number } & 15 & 20 & 47 & 28 & 8 & 16 & 25 & 159 \\
\hline
\end{tabular}

на їх текстуальність. Для досягнення мети у статті розглянуто останні роботи, які стосуються інтернет-мемів, визначено шляхи імплементації мемів у політичному дискурсі, встановлено специфіку вербалізації мемів із політичним контекстом, досліджено частоту використання політичних інтернет-мемів, спираючись на їх тип. Авторка виокремлення три основні типи політичних інтернет-мемів, спираючись на їх текстуальні особливості, а саме: текстуальні (оригінальні, симбіотичні, інтегральні, зрощенні, фразові), нетекстуальні (оригінальні, зрощенні, пікторальні), анімативні (GIFки, фрагментальні). Стаття побудована на результатах дослідження, яке включає опрацювання інтернет-мемів, що були цілеспрямовано відібрані із соціальної мережі Instagram, а саме 3 офіційних новинних агенцій, які представлені онлайн: BBC News, CNN, MSNBC, NBC News, The Times, Politico, i Washington Post. У статті опрацьовано інтернет-меми, які мають політичний контекст і стосуються Сполучених Штатів Америки і Об'єднаного Королівства. Інтенція формування мемів залежить від умов і потреб часу, за яких їх було створено. У березні-квітні 2021 року цими факторами стали: всесвітня пандемія коронавірусу, страйки у Сполучених Штатах Америки, британська монархія, локдауни, президентські вибори у Сполучених Штатах Америки, які відбулися між представником Республіканської партії 45 президентом Сполучених Штатів Америки Дональдом Трампом і представником Демократичної партії, новообраним 46 президентом Сполучених Штатів Америки Джо Байденом. Ковід-19 відтворюється низкою лексичних і візуальних засобів, як-от медичні маски, дистанція, страйки репрезентуються чорно-білими кольорами. Таким чином, вибірка інтернетмемів спрямована на зображення способів вербалізації можливість політичних діячів для подолання хаосу сьогодення. Авторка дійшла висновків, що текстуальні меми посідають перше місце за поширеністю, на другому - нетекстуальні політичні меми, а анімативні посідають лише третє місце за частотою використання.

Ключові слова: меми, політичний дискурс, політичні меми, текстуальність, контекст. 